\title{
MANAJEMEN ANESTESIA PADA ANAK DENGAN NASOFRONTAL MENINGOENCEPHALOCELE DAN HYDROCEPHALUS NON- COMMUNICANT
}

\author{
ANESTHESIA MANAGEMENT FOR A CHILD WITH \\ MENINGOENCEPHALOCELE AND HYDROCEPHALUS NON \\ COMMUNICANT
}

\author{
Erfprinsi Wohon, Bambang Harijono, Siti Chasnak Saleh \\ Departemen Anestesiologi \& Terapi Intensif \\ Fakultas Kedokteran Universitas Airlangga \\ RSUD.Dr.Soetomo, Surabaya
}

\begin{abstract}
Meningoencephaloceles are very rare congenital malformations in the world that have a high incidence in the population of Southeast Asia, include in Indonesia. Children with nasofrontal meningoencephaloceles should have surgical correction as early as possible because of the facial dysmorphia, impairment of binocular vision, increasing size of the meningoencephalocele caused by increasing brain prolapse, and risk of infection of the central nervous system. In this report, we presented a case of a 9 months-old baby girl with nasofrontal meningoencephalocele and hydrocephalus non communican, posted for VP shunt (ventriculo-peritoneal shunt) and cele excision. Because of the mass, nasofrontal or frontoethmoidal and occipital meningoencephalocele leads the anaesthetist to problems since the preoperative visit, time of induction, maintenance of anaesthesia during the operation until post operative care. Anaesthetic challenges in management of meningoencephalocele, which most of the patients are children, include ventilation, intubation and securing the airway with intubation with the mass in nasofrontal and nasoethmoidal with its associated complications and accurate assessment of bloodloss and prevention of hypothermia.
\end{abstract}

Key words : Anesthesia, Difficult ventilation, Difficult intubation, Nasofrontal Meningoencephalocele, Pediatrics.

JNI 2012; 1 (1):39-43

\begin{abstract}
Abstrak
Meningoencephalocele adalah defek kongenital yang sangat jarang, tapi insidennya tinggi di Asia Tenggara, termasuk di Indonesia. Penderita dengan nasofrontal meningoencephalocele memerlukan koreksi pembedahan sedini mungkin karena adanya kelainan bentuk wajah, gangguan pandangan, bertambahnya ukuran meningoencephalocele disebabkan bertambahnya prolaps cerebri dan risiko infeksi. Dalam laporan ini kami presentasikan kasus seorang bayi 9 bulan dengan meningoencephalocele naso-orbital dan hydrocephalus non communican yang menjalani operasi VP shunt dan eksisi cele. Adanya massa tersebut, baik meningoencephalocele nasofrontal atau frontoethmoidal maupun occipital, menimbulkan kesulitan bagi ahli anestesi mulai saat induksi, pemeliharaan anestesi dan pasca operasinya. Menjadi tantangan bagi ahli anestesi dalam pengelolaan meningoencephalocele, dimana sebagian besar penderitanya adalah anak-anak yang mempunyai kesulitan tersendiri, termasuk mengamankan jalan nafas dengan intubasi dan adanya massa yang akan mempersulit ventilasi saat induksi, adanya massa pada nasofrontal serta nasoethmoidal yang berhubungan dengan komplikasinya dan penilaian yang tepat terhadap perdarahan dan hipotermia.
\end{abstract}

Kata kunci : Anestesia, Intubasi sulit, Nasofrontal Meningoencephalocele, Pediatri, Ventilasi sulit.

JNI 2012; 1 (1):39-43

\section{Pendahuluan}

Meningoencephalocele adalah kelainan kongenital yang banyak didapat di Asia Tenggara. Meningocele frontoethmoid adalah jenis yang paling banyak ditemukan dan membutuhkan tindakan pembedah- an. Di Asia Tenggara (Thailand, Burma dan Cambodia) dan sebagian di India, Russia dan Afrika Tengah, kejadian tertinggi didapatkan 1 penderita dari 3500 kelahiran hidup, dimana ini lebih tinggi daripada di Australia, Amerika Utara, Jepang, Hong Kong dan Eropa Barat dimana 
kejadianya 1 dari 35.000 kelahiran hidup. Lokasi di frontoethmoid adalah jenis meningoencephalocele anterior yang paling sering. ${ }^{1}$

Bayi dengan meningoencephalocele awalnya normal saat lahir secara neurologis. Bentuk cephalocele muncul sebagai nodul subkutan nonkistik yang kecil dan sering tanpa keluhan klinis yang berarti. Lesi ini seperti kantong dan ukurannya bervariasi. ${ }^{2}$ Penderita dengan mening-oencephalocele anterior memerlukan koreksi pembedahan sedini mungkin karena adanya kelainan bentuk wajah, gangguan visual, bertambahnya ukuran meningoencephalocele yang di-sebabkan bertambahnya prolaps cerebri dan risiko infeksi sistem saraf pusat. ${ }^{1}$ Problem mata dapat dijumpai seperti bertambahnya jarak intercanthus dan interpupil, penurunan visual dan gangguang drainase kelenjar lacrimalis. Serta dapat disertai kelainan neurologis yang lain seperti retardasi mental, hydrocephalus atau epilepsi. ${ }^{3}$

Menjadi tantangan bagi ahli anestesi dalam pengelolaan meningoencephalocele nasoorbital, termasuk mengamankan jalan nafas dengan intubasi dan adanya massa yang akan mempersulit ventilasi saat induksi, serta dengan adanya massa pada nasofrontal atau nasoethmoidal yang berhubungan dengan komplikasinya dan penilaian yang tepat terhadap perdarahan dan hipotermia. 4.5

\section{Kasus}

Seorang bayi perempuan usia 9 bulan dengan berat badan 7,3 kilogram, dengan diagnosa meningoencephalocele nasofrontal dan hidrocephalus noncommunican dijadwalkan untuk operasi eksisi cele dan VP (ventriculo-peritoneal) shunt. Dari anamnesa didapatkan terdapat massa di hidung sejak lahir, dengan ukuran awal sebesar kacang dan makin lama makin bertambah besar, saat ini massa sebesar telur. Tidak ada defisit neurologis dan gangguan pertumbuhan.

\section{Pemeriksaan Fisik :}

Dari pemeriksaan fisik tidak didapatkan kelainan kongenital lainnya, pemeriksaan jantung dan sistem pernapasan dalam batas normal. Jalan nafas bebas dengan laju nafas 24 kali per menit, simetris, suara nafas simetris dan tidak terdengar suara ronki maupun wheezing. Nadi 118 kali per menit, regular dan suhu badan $37^{\circ} \mathrm{C}$. Penderita sadar dan aktif dengan gerak tangis kuat, dan panjang FOC (Fronto-Occipito Circumference) $48 \mathrm{~cm}$. Didapatkan hipertelorisme karena massa nasoorbital dan pupil isokor. Ukuran massa sekitar $8 \times 7 \times 5$ centimeter.

\section{Pemeriksaan Laboratorium}

Dari hasil laboratorium, hemoglobin $11,3 \mathrm{mg} / \mathrm{dl}$, hematokrit 34,3 dan hasil pengukuran laboratorium lainnya dalam batas normal.
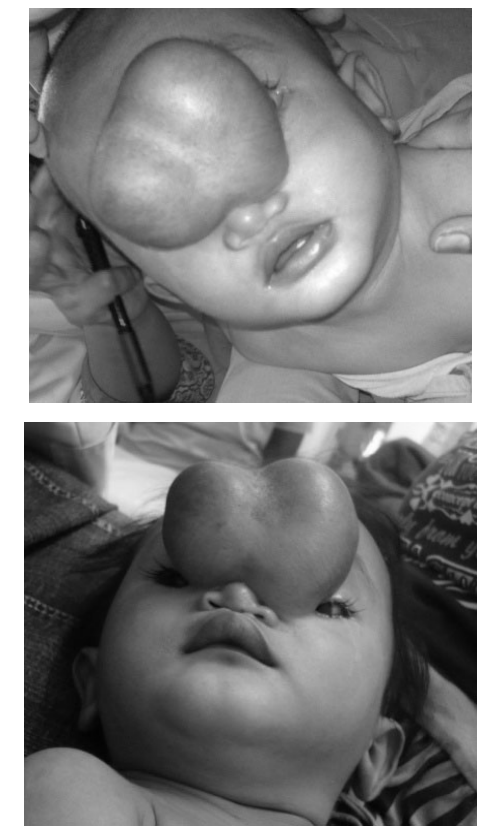

Gambar 1. Pre-operative, naso-frontal meningoencephalocele
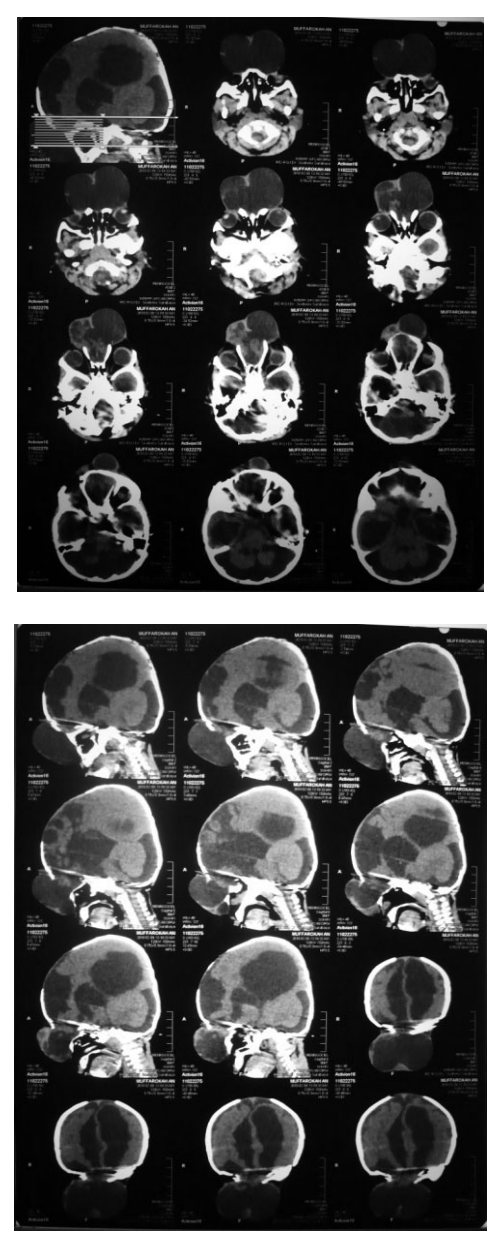


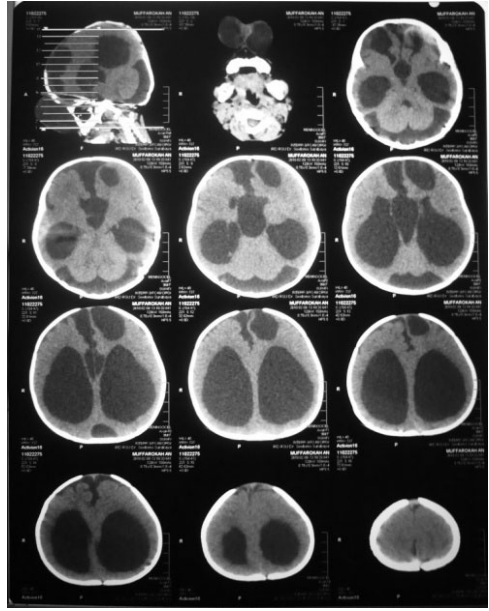

Gambar 2. CT scan

Tidak didapatkan kelainan neurologis. CT scan menunjukkan meningoencephalocele frontoethmoid dan hidrocephalus non-communican.

Pembedahan meliputi 2 prosedur, yaitu VP (Ventriculo-Peritoneal) shunt dan eksisi cele, sehingga membutuhkan waktu pembedahan yang lama dan persiapan yang baik terutama untuk penderita pediatri.

\section{Persiapan Prabedah}

Penderita dipuasakan 4 jam sebelum pembedahan untuk tidak minum air putih dan 6 jam untuk tidak makan makanan padat dan susu. Selama puasa dijadwalkan untuk pemberian infus pemeliharaan dengan Dextrose 5\% 0,225 Normal Saline, tetapi penderita tidak dapat dipasang infus sampai penderita dibawa ke ruang operasi. Satu kantong darah PRC (packed red cells) disiapkan bila terjadi perdarahan. Obat-obatan darurat disiapkan di ruang operasi. Monitor dengan elektroda elektrokardiografi, tekanan darah, suhu rectal, dan pulse oxymetri dan stetoskop precordial dipasang sebelum mulai induksi dan alat suction menyala dan siap digunakan. Matras penghangat digunakan untuk menjaga suhu penderita juga dengan membungkus ekstremitasnya dengan under-pad, serta disiapkan menghangatkan cairan infus yang akan diberikan selama operasi.

\section{Pengelolaan Anestesi}

Penderita diinduksi dengan halotan insuflasi dengan masker $\mathrm{O}_{2} 100 \%$ pada posisi supine, dan kemudian diinfus dengan kateter infus ukuran 24 gauge dilanjutkan cairan pemeliharaan dengan Dextrose 5\% 0.225 normal saline. Sulfas atropin 0.1 miligram diberikan sebagai premedikasi dan setelah mencapai tahap kedalaman anestesia, penderita diintubasi dengan endotracheal tube tanpa balon ukuran 4.0 dan kemudian diperiksa suara nafas simetris. Dipastikan kedalaman tube dengan benar dan fiksasi dengan baik pada kedalaman $12 \mathrm{~cm}$ dengan plester ketat, setelah itu dilakukan insersi tampon. Penderita diposisikan dengan hati-hati dan kerjasama dengan tim bedah saraf untuk mencegah tube terekstubasi.

Kontrol ventilasi dilakukan manual dengan Jackson Rees dan maintenance anestesia dengan Isofluran $1-1.5 \%$ dengan O2 100\%. Selama operasi untuk analgetik diberikan Fentanyl total 20 microgram dan Morphin 1 miligram, dan pelumpuh otot digunakan Vecuronium 0.5 miligram.

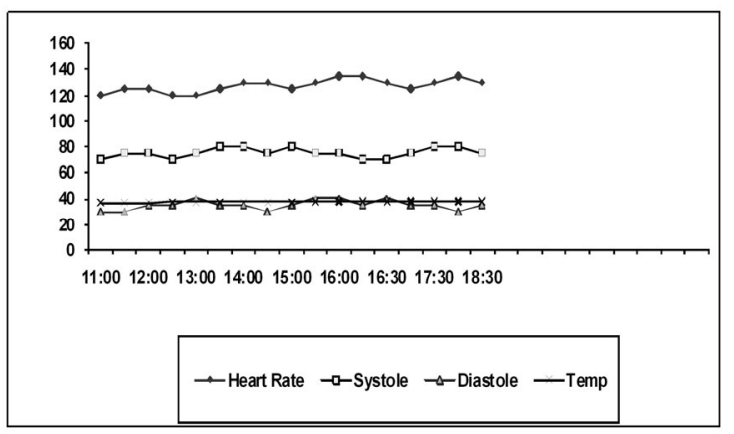

Gambar 3. Hemodinamik penderita durante operasi

Selama operasi, hemodinamik penderita stabil, tekanan darah sistole $70-80 \mathrm{mmHg}$ dan diastole 20 $35 \mathrm{mmHg}$, nadi $120-135$ kali per menit, dan suhu 37.3 - 37.9 oC. Perdarahan total sekitar $125 \mathrm{cc}$ dan diganti dengan 125 cc packed red cell dan cairan pemeliharaan dengan Normal Saline $300 \mathrm{cc}$ dan Dextrose $5 \%$ in 0.225 Normal Saline 100 cc. Operasi berlangsung sekitar 7 jam. Setelah operasi dilakukan ekstubasi endotrakheal dan diberikan Metamizole $150 \mathrm{mg}$ untuk analgetik pasca operasi. Ekstubasi dilakukan setelah dihentikan pemberian Isofluran dan refleks-refleks jalan nafas telah kembali. Penderita selanjutnya diobservasi di ruang pulih sadar dan kemudian dipindah untuk observasi di unit perawatan intermediate dengan tidak ada tanda-tanda distres nafas. Penderita membaik dengan cepat dan keluar dari rumah sakit pada lima belas hari kemudian.

\section{III.Pembahasan}

Optimalisasi preoperatif yang baik sangat diperlukan untuk meminimalisasi risiko dan meningkatkan keselamatan penderita. Pada kasus ini, masalah preoperatif yang penting adalah massa yang besar dan lunak di hidung atas sampai diantara mata penderita yang membuat kesulitan ventilasi dan intubasi. Pengelolaan jalan nafas pada penderita dengan kelainan kraniofacial memberikan tantangan bagi ahli anestesi, sehingga harus 
direncanakan dengan baik termasuk pengetahuan bagaimana anatomi yang ada akan mempengaruhi saat diberikan ventilasi dengan masker dan intubasi endotrakhea. ${ }^{5}$ Penderita anak mempunyai volume cadangan yang rendah, sehingga kegagalan intubasi dapat menyebabkan hipoksemia, bradikardi dan bahkan cardiac arrest. Maka diperlukan juga persiapan untuk resusitasi. ${ }^{6}$ Persiapan alat dan tim yang baik harus disiapkan dengan lengkap. Berbagai macam jenis dan ukuran masker disiapkan dan dipilih yang tepat dan lunak terhadap kulit dan memberi penekanan yang lembut dan hindari trauma pada cele atau kantong. ${ }^{7}$ Karena adanya massa cele, masker tidak dapat ditempatkan ke hidung penderita seperti biasa. Beberapa teknik dapat digunakan untuk mempertahankan ventilasi yang tepat, diantaranya dengan menggunakan masker dengan cara dibalik atau dipilih masker yang besar sehingga cele dapat ikut masuk didalam masker. Alat bantu seperti orofaring tube harus siap bila diperlukan sewaktu-waktu, juga sumber oksigen tambahan melalui naso gastric tube yang dimasukkan ke faring melalui hidung dapat digunakan.

Pemilihan agent untuk induksi dengan halotan dan intubasi non-apnea tepat untuk kasus ini karena ada dugaan kesulitan ventilasi dan intubasi pada penderita tersebut. Pipa endotrakheal tanpa cuff yang non-kinked dan fiksasi yang kuat diperlukan karena area pembedahan di wajah penderita.

Anestesia umum dipilih pada pembedahan ini dan harus dipertahankan anestesia dan analgesia yang adekuat, monitoring ketat respirasi dan kondisi hemodinamik, antisipasi pada setiap masalah yang timbul selama operasi sampai pasca operasi. Selama operasi dilakukan kontrol ventilasi untuk mempertahankan $\mathrm{pO}_{2}$ dan $\mathrm{pCO}_{2}$ yang normal. Status kardiovaskular dan temperatur dimonitor sepanjang operasi, dengan menggunakan tekanan darah, EKG dan suhu rektal secara kontinyu. Karena penderita adalah pediatri yang lebih rentan dan membutuhkan monitoring akurat mengenai perdarahan dan pencegahan hipotermia selama operasi. Menggunakan lampu penghangat inftra merah saat tahap persiapan dan selimut penghangat selama operasi membantu dalam mempertahankan suhu tubuh. ${ }^{4}$ Halotan insuflasi dan teknik intubasi nonapnea yang dipilih untuk induksi seharusnya memberikan pengaruh minimal pada gangguan hemodinamik. Diperlukan perhatian lebih terhadap perdarahan, mempertahankan suhu tubuh dan komplikasi yang menyertai serta hati-hati mengamankan posisi pipa endotrakheal. Merupakan tantangan anestesi yang utama dalam pengelolaan meningoncephalocode adalah pengelolaan jalan nafas, menjaga pipa endotrakheal, penilaian status volume dan pencegahan hipotermi. ${ }^{5,8,9,10}$ Maka monitoring intensif diperlukan selama operasi untuk estimasi perdarahan dan cairan penggantiannya. Obat-obat da-rurat harus ditempatkan di tempat yang mudah dijangkau untuk mempertahankan stabilitas hemo-dinamik selama dan pasca operasi. Nyeri harus dikontrol dengan menggunakan analgesik yang tepat.

\section{Simpulan}

Anestesia pada penderita dengan meningocele dan hidrocefalus non communican memerlukan banyak perhatian khusus sejak preoperatif, induksi, durante operasi dan pasca operasi. Optimalisasi dan persiapan perioperatif yang baik dapat menurunkan risiko dan memperbaiki kondisi penderita serta merupakan strategi terbaik bagi pengelolaan penderita. Pengelolaan kasus meningoencephalocele termasuk juga mencari kelainan kongenital yang lain, pengelolaan jalan nafas yang baik dan perawatan intraoperatif termasuk penempatan posisi yang tepat dan penggantian cairan perdarahan. Walaupun ahli anestesi bertanggung jawab akan kondisi penderita selama perioperatif, tetapi juga diperlukan kerjasama dengan bagian lain untuk penatalaksanaan penderita dan perhatian khusus terhadap masalah yang mungkin terjadi.

\section{Daftar Pustaka}

1. Pinzer T, Lauer G, Gollogly J, Schackert G. A complex therapy for treatment of frontoethmoidal meningoencephalocele in a developing third world country: neurosurgical aspects. Journal of Neurosergery: Pediatrics. 2006 May;104(5):326-31.

2. Quezado Z, Finkel JC. Airway Management in Neonates with Occipital Encephalocele : Easy

Does It. Anesth Analg 2008

October;107(4):1446.

3. Creighton RE, Relton JES, Meridy HW. Anaesthesia for Occipital Encephalocele. Canada Anaesthesia Society Journal. 1974 July;21(4):403-6.

4. Mahajan C, Rath GP. Anaesthetic management in a child with frontonasal encephalocele. Journal of Anaesthetic Clinical Pharmacology. 2010;26(4):570-1.

5. Towfighi J, Sarnat HB. Cephaloceles. Neurology Medlink. 1995 October [updated 2010 Des 12]. Available from : http://www.medlink.com/medlinkcontent.asp 
6. Singh KV. Giant Occipital

Meningoencephalocele : Anaesthetic

Implications. The Internet Journal of

Anaesthesiology. 2007;13(2). Available from :

http://www.ispub.com/journal/the internet jou rnal_of anesthesiology/volume 13 number 2

1/article_printable/giant_occipital_meningoen cephalocele anaesthetic implications.html

7. Ahmed N, Ahmed M, Mendolkar S, Mahaldar AMG. Lateral Thoracic Meningocele :

Anesthetic Implications. Al Ameen Journal Med Sci. 2008;1(2):136-8.

8. Goel V, Dogra N, Khandelwal M, Chaudhri RS. Management of neonatal giant occipital encephalocele: Anaesthetic challenge. Indian Journal of Anaesthesia. 2010;54(5):477-8.

9. Gordon G. Nasal Encephalocele. Pediatric Anesthesiology - Neonatal Emergencies. 2004 February[cited 2004 Feb 19]. Available from : http://metrohealthanesthesia.com/edu/ped/PBL DNeonate1.htm

10. David DJ. New perspectives in the management of severe cranio-facial deformity. Annuals of the Royal College of Surgeons of England. 1984;66:270-9. 